\begin{tabular}{c} 
Brazilian Journal \\
of Chemical \\
Engineering \\
\hline
\end{tabular}

ISSN 0104-6632

Printed in Brazil

www.abeq.org.br/bjche

Vol. 32, No. 03, pp. 749 - 755, July - September, 2015

dx.doi.org/10.1590/0104-6632.20150323s00003356

\title{
PRODUCTION OF LACTIC ACID FROM GLYCEROL BY APPLYING AN ALKALINE HYDROTHERMAL PROCESS USING HOMOGENEOUS CATALYSTS AND HIGH GLYCEROL CONCENTRATION
}

\author{
A. K. O. Rodrigues, D. L. H. Maia and F. A. N. Fernandes* \\ Universidade Federal do Ceará, Departamento de Engenharia Química, \\ Campus Universitário do Pici, Bloco 709, 60455-760, Fortaleza - CE, Brazil. \\ Phone: + (55) (85) 33669611, Fax: + (55) (85)33669610 \\ E-mail: fabiano@ufc.br
}

(Submitted: March 12, 2014 ; Revised: October 12, 2014 ; Accepted: November 22, 2014)

\begin{abstract}
The production of lactic acid from glycerol by means of the alkaline hydrothermal process was evaluated using high concentrations of glycerol. The operating conditions that influence the hydrothermal process were studied. Temperature $\left(250-280^{\circ} \mathrm{C}\right)$, catalyst to glycerol molar ratio $(0.05$ to 0.15$)$, and water to glycerol volumetric ratio ( 0.8 to 1.5 ) were evaluated, as well as the use of $\mathrm{NaOH}$ and $\mathrm{KOH}$ as catalysts. A concentration of lactic acid of $122 \mathrm{~g} / \mathrm{L}$ was obtained at $260{ }^{\circ} \mathrm{C}, 0.04 \mathrm{NaOH}$ to glycerol molar ratio, 1.0 water to glycerol volumetric ratio and $3 \mathrm{~h}$ of reaction using crude glycerol as raw material. The results showed higher lactic acid concentration and productivity than the fermentative process and the hydrothermal process carried out using low initial glycerol concentration.

Keywords: Glycerol; Lactic acid; Hydrothermal processing; Homogeneous catalyst.
\end{abstract}

\section{INTRODUCTION}

The use and development of renewable energy sources is growing. Biodiesel, one of the alternatives to petroleum-derived diesel fuels, has been developed and is being produced in large industrial scale in several countries. As the production of biodiesel grows, the production of its main by-product (glycerol) also grows. The production of 10 tons of biodiesel generates about 1 ton of glycerol $(\sim 10 \mathrm{wt} \%)$, which has begun to be considered an unwanted byproduct since it cannot be simply dumped into rivers or landfills (Dasari et al., 2005). In recent years, the availability of glycerol increased and new markets and uses for glycerol are required and desired.
Lactic acid is one of the products that can be obtained from glycerol. Currently, it is used as a precursor for green solvents such as ethyl lactate and in the synthesis of poly(lactic acid), which is a biodegradable polymer. Lactic acid has many applications in the food, textile, leather, cosmetic, chemical and pharmaceutical industries (Ramírez-López et al., 2011)

More than $90 \%$ of the lactic acid is produced by fermentation of carbon sources, especially sugars and alcohols (He et al., 2008). The fermentative process has a high selectivity towards lactic acid, but the concentration of lactic acid at the end of the fermentation can be considered low (approximately $50 \mathrm{~g} / \mathrm{L}$ ). Only a few strains of lactic bacteria provides high

*To whom correspondence should be addressed 
concentrations of lactic acid (approximately $100 \mathrm{~g} / \mathrm{L}$ ) (Budhavaram and Fan, 2009; Gullon et al., 2008; Marques et al., 2008; Nancib et al., 2009).

Glycerol can be converted into lactic acid and other products by hydrothermal processes (Savage, 1999; Shen et al., 2009). The hydrothermal process can be carried out by an alkaline process using a hydroxide as catalyst (usually $\mathrm{NaOH}$ or $\mathrm{KOH}$ ) or by heterogeneous catalysis using a wide range of oxides as catalyst (Ca, $\mathrm{Cu}, \mathrm{Ni}, \mathrm{Au}, \mathrm{Zn}$ oxides) (Chen et al., 2014; Hu et al., 2012; Purushothaman et al., 2014; Roy et al., 2011; Xu et al., 2013). In this work, we have focused on the alkaline hydrothermal process to produce lactic acid. The conversion of glycerol to lactic acid (or its lactate) by the alkaline process proceeds through the reactions:

$$
\begin{aligned}
& \mathrm{C}_{3} \mathrm{H}_{8} \mathrm{O}_{3}+\mathrm{H}_{2} \mathrm{O} \rightarrow \mathrm{C}_{3} \mathrm{H}_{6} \mathrm{O}_{3}+\mathrm{H}_{2}+\mathrm{H}_{2} \mathrm{O} \\
& \mathrm{C}_{3} \mathrm{H}_{6} \mathrm{O}_{3}+\mathrm{NaOH} \rightarrow \mathrm{C}_{3} \mathrm{H}_{5} \mathrm{O}_{3} \mathrm{Na}+\mathrm{H}_{2} \mathrm{O}
\end{aligned}
$$

Several studies have reported high yields of lactic acid (> 90\%) from many carbon sources (glycerol, sorbitol, mannitol) (Kishida et al., 2005; RamírezLópez et al., 2010; Shen et al., 2009; Zhou et al., 2010). These studies, however, started from low concentrations of the carbon source $(<0.05 \mathrm{v} / \mathrm{v})$. Under this condition, the final concentrations of lactic acid and the productivities of the process are much lower than the concentrations and productivities observed in the fermentative process. To compete with the fermentative process, the hydrothermal process needs to be equivalent or better than the fermentative process.

In this work, the hydrothermal process to produce lactic acid from glycerol was evaluated using high initial concentrations of glycerol $(>0.8 \mathrm{v} / \mathrm{v})$, aiming at an increase in productivity. The main process variables (temperature, catalyst/glycerol mass ratio and water/glycerin volumetric ratio) were studied and their influences on yield and productivity were evaluated.

\section{MATERIALS AND METHODS}

\section{Materials}

All reagents were obtained from Synth (Brazil). Crude glycerol derived from biodiesel production was provided by Petrobras Biocombustível (Quixadá - CE, Brazil).

\section{Hydrothermal Reaction}

The chemical reaction was carried out in a 400 $\mathrm{mL}$ batch autoclave reactor (Metalquim, Brazil) made of stainless steel, equipped with temperature and pressure control and a magnetic stirrer. The reactions were carried out by adding glycerol, water and catalyst (sodium or potassium hydroxide) to the reactor, according to the ratios presented in Tables 1,3 and 4 . The volume of reagents in the reactor was always set to $200 \mathrm{~mL}$ and the stirrer speed was set at $800 \mathrm{rpm}$. The reactor was closed and heating began after adding the reagents. Reaction time was set to 3 $\mathrm{h}$ after reaching the final reaction temperature (about $20 \mathrm{~min}$ after heating started). After $3 \mathrm{~h}$, the reactor was rapidly cooled by passing a cold-water stream $\left(23{ }^{\circ} \mathrm{C}\right)$ through the reactor jacket.

The $\mathrm{NaOH}$ to glycerol molar ratios presented in Tables 1, 3 and 4 correspond to the same concentration range of $\mathrm{NaOH}$ in the reactor. The difference in numerical value is due to the higher amount of glycerol that was added to each reaction.

\section{Chemical Analysis}

Lactic acid was converted into methyl lactate prior to $\mathrm{GC}$ analysis, for better analysis of the results because GC-FID has very poor sensitivity for lactic acid. Derivatization was carried out by mixing 10 $\mathrm{mL}$ of reaction mixture with $25 \mathrm{~mL}$ of methanol and 6 drops of $\mathrm{H}_{2} \mathrm{SO}_{4}$. The derivatization reaction was carried out overnight at ambient temperature. The calculation of methyl lactate concentration was based on a five point calibration curve constructed using methyl lactate analytical standard (85\%) as reference. The derivatization carried out to quantify lactic acid also quantifies the lactate salts because, when sulfuric acid is added to the sample, any lactate salt will be transformed into lactic acid, which is then esterified into methyl lactate. Thus, the formation of lactate salts will be accounted for and expressed as lactic acid.

The samples were analyzed by GC-FID (Thermos model Ultra) using an OV-1 capillary column $30 \mathrm{~m}$ in length with $0.25 \mathrm{~mm}$ inner diameter and $0.25 \mu \mathrm{m}$ film thickness. The injector temperature was set at $250{ }^{\circ} \mathrm{C}$. Oven temperature started at $50{ }^{\circ} \mathrm{C}$ and was increased to $150{ }^{\circ} \mathrm{C}$ at a rate of $5^{\circ} \mathrm{C} / \mathrm{min}$ and held for 2 min.

Glycerol content was analyzed by FTIR (Agilent model Cary 630). An amount of $300 \mu \mathrm{L}$ of sample was directly analyzed in the ATR module of the FTIR equipment. The spectral resolution was $4 \mathrm{~cm}^{-1}$ and 32 scans were accumulated for each spectrum. A 
spectral range between 800 and $400 \mathrm{~cm}^{-1}$ was measured. The values obtained at $1420 \mathrm{~cm}^{-1}$ were recorded and used to calculate the concentration of glycerol in the sample. The calculation of glycerol concentration was based on a five point calibration curve constructed using glycerol solutions in distilled water.

The conversion of glycerol was calculated with Equation (3),

$$
X=\frac{n_{G}^{0}-n_{G}}{n_{G}^{0}}
$$

where $n_{G}^{0}$ is the initial number of mols of glycerol, $n_{G}$ is the number of mols of glycerol obtained after the analysis of the sample, and $X$ is the conversion of glycerol.

By-products and trace elements were analyzed by GCMS (Thermos model ISQ) under the same conditions used for GC analysis (column, injector temperature and oven programming).

\section{RESULTS AND DISCUSSION}

Experiments with low initial concentration of glycerol were carried out as a basis for comparison between the hydrothermal processes using high and low initial concentrations of glycerol. The yields of conversion of glycerol into lactic acid under these conditions are presented in Table 1. The results showed yields up to $76.4 \%$.

Glyceraldehyde, propionaldehyde and gluconic acid were formed during the reaction, but in minor amounts. The conversion of glycerol into these other by-products was between 0.5 and 3\%. Propionaldehyde was the main by-product at the lowest temperature $\left(240{ }^{\circ} \mathrm{C}\right)$ and glyceraldehyde was the main byproduct at the highest temperature $\left(260^{\circ} \mathrm{C}\right)$.
Table 2 presents the analysis of perturbation of the factors for the hydrothermal process carried out at low glycerin to water molar ratio. The process was mainly influenced by temperature and $\mathrm{NaOH}$ to glycerol molar ratio. Higher temperatures and lower $\mathrm{NaOH}$ to glycerol molar ratios resulted in higher yields of lactic acid. The statistical analysis indicated that the catalyst to glycerol molar ratio was the main factor influencing the reaction; presenting a negative effect on the hydrothermal process (an increase in the $\mathrm{NaOH}$ to glycerol molar ratios produced a decrease in yield).

According to Ramirez et al. (2011), the decrease in yield at excess hydroxide ion concentrations is caused by the scission of glycerol at different $\mathrm{C}-\mathrm{C}$ bonds, resulting in an increasing number of competing reactions, which include the reactions of decomposition of lactic acid, decomposition of reaction intermediates, and the activation of conversion routes of pyruvaldehyde and formate.

The results obtained herein were lower than those reported by Shen et al. (2009), who obtained yields up to $90 \%$ from the same initial water, glycerol and $\mathrm{NaOH}$ concentrations, but under a more severe operating condition $\left(300{ }^{\circ} \mathrm{C}\right.$ and 90 bar). The difference in the results shows the importance of operating at higher temperatures if higher yields are desired. A comparison between the results reported herein and by Shen et al. (2009) shows a change in the behavior of the reaction regarding the $\mathrm{NaOH} /$ glycerol molar ratios. Table 1 shows that the yield decreased with increasing $\mathrm{NaOH} /$ glycerol ratios, while Shen's results show the opposite behavior (yield increasing with increasing $\mathrm{NaOH} /$ glycerol ratios). The different behavior that was observed may be related to a thermal effect, which may increase the rate of reaction more at high $\mathrm{NaOH} /$ glycerol ratios than at low $\mathrm{NaOH} /$ glycerol ratios, leading to the differences in behavior found between the studies.

Table 1: Yield and lactic acid productivity for the hydrothermal treatment of glycerol carried out at low initial glycerol concentration.

\begin{tabular}{|c|c|c|c|c|c|c|}
\hline Run & $\begin{array}{c}\text { Temperature } \\
\left({ }^{\circ} \mathbf{C}\right)\end{array}$ & $\begin{array}{c}\text { Water to Glycerol } \\
\text { volumetric ratio } \\
(\mathbf{v} / \mathbf{v})\end{array}$ & $\begin{array}{c}\text { NaOH to Glycerol } \\
\text { molar ratio } \\
(\mathbf{m o l} / \mathbf{m o l})\end{array}$ & $\begin{array}{c}\text { Yield } \\
\mathbf{( \% )}\end{array}$ & $\begin{array}{c}\text { Lactic Acid } \\
\text { Concentration } \\
\mathbf{( g / L})\end{array}$ & $\begin{array}{c}\text { Lactic Acid } \\
\text { Productivity } \\
(\mathbf{g} / \mathbf{L} . \mathbf{h})\end{array}$ \\
\hline 1 & 247 & 31.0 & 0.44 & 67.6 & 26.0 & 8.7 \\
2 & 250 & 31.0 & 0.44 & 76.4 & 29.4 & 9.8 \\
3 & 240 & 27.0 & 0.44 & 51.1 & 22.5 & 7.5 \\
4 & 250 & 31.0 & 0.73 & 51.3 & 29.7 & 6.6 \\
5 & 252 & 31.0 & 0.73 & 53.4 & 20.5 & 6.8 \\
6 & 245 & 27.0 & 0.73 & 50.2 & 22.1 & 7.4 \\
7 & 241 & 31.0 & 1.02 & 47.1 & 18.1 & 6.0 \\
8 & 244 & 31.0 & 1.02 & 50.2 & 19.3 & 6.4 \\
9 & 240 & 27.0 & 1.02 & 43.4 & 19.1 & 6.4 \\
\hline
\end{tabular}


Table 2: Analysis of perturbation of the factors on the yield of lactic acid for the hydrothermal process carried out at low and at high glycerol concentration".

\begin{tabular}{|c|c|c|}
\hline Factor & Effect & p Value \\
\hline \multicolumn{3}{|c|}{$\begin{array}{l}\text { Hydrothermal process carried out with low glycerol } \\
\text { concentration }\end{array}$} \\
\hline Mean & $50.13 \pm 2.00$ & 0.0001 \\
\hline $\mathbf{T}$ & $14.41 \pm 3.81$ & 0.0325 \\
\hline$T^{2}$ & $-8.55 \pm 4.16$ & 0.1317 \\
\hline Cat & $-17.24 \pm 3.34$ & 0.0141 \\
\hline Cat $^{2}$ & $18.19 \pm 5.56$ & 0.0467 \\
\hline T x Cat & $-11.27 \pm 4.55$ & 0.0895 \\
\hline \multicolumn{3}{|c|}{$\begin{array}{l}\text { Hydrothermal process carried out with high glycerol } \\
\text { concentration }\end{array}$} \\
\hline Mean & $7.20 \pm 1.71$ & 0.0040 \\
\hline $\mathbf{T}$ & $3.17 \pm 5.18$ & 0.5586 \\
\hline Cat & $-6.01 \pm 2.15$ & 0.0268 \\
\hline T X Cat & $0.50 \pm 2.70$ & 0.8579 \\
\hline
\end{tabular}

*Variables in bold represent significant influence at $90 \%$ of significance. $\mathrm{T}$ - temperature; Cat - catalyst to glycerol molar ratio.

Lactic acid concentration and productivity obtained by Shen et al. (2009) were $26.7 \mathrm{~g} / \mathrm{L}$ and $8.9 \mathrm{~g} / \mathrm{L} . \mathrm{h}$, respectively. In our research, higher lactic acid concentrations and productivity were obtained (Run 2, Table 1). As such, it is possible to achieve higher productivity under less severe operating conditions, especially under lower temperature and, thus, with lower energy consumption.

Typical fermentation processes for lactic acid production output lactic acid concentrations between 50 to $60 \mathrm{~g} / \mathrm{L}$ and productivities between 1.0 to $5.0 \mathrm{~g} / \mathrm{L} . \mathrm{h}$ (Guilherme et al., 2011; Oliveira et al., 2009; Silveira et al., 2010). For example, the production of lactic acid employing molasses from hydrolyzed sugarcane fermented by Lactobacillus casei presented a maximum concentration of lactic acid of $58.9 \mathrm{~g} / \mathrm{L}$ and a maximum yield of $1.2 \mathrm{~g} / \mathrm{L} . \mathrm{h}$ (Oliveira et al., 2009). The production of lactic acid employing cashew apple juice fermented by Lactobacillus casei presented a maximum concentration of lactic acid of $59.3 \mathrm{~g} / \mathrm{L}$, yields up to $96 \%$ and a maximum productivity of $1.7 \mathrm{~g} / \mathrm{L} . \mathrm{h}$ (Guilherme et al., 2011). Gullon et al. (2008) obtained productivities as high as $5.1 \mathrm{~g} / \mathrm{L}$.h with a lactic acid concentration of 32.5 $\mathrm{g} / \mathrm{L}$ fermenting apple pomace. High productivities (between 19 and $22 \mathrm{~g} / \mathrm{L} . \mathrm{h}$ ) and concentrations up to $38 \mathrm{~g} / \mathrm{L}$ were reported by (Schepers et al., 2006) fermenting whey permeate and yeast extract using $\mathrm{Lac}$ tobacillus helveticus to produce lactic acid. Higher productivities than the hydrothermal process carried out with low glycerol concentration were also reported by Plessas et al. (2008) and by Coelho et al. (2011).

Although high yields can be obtained by the hydrothermal process, the concentration of lactic acid in the reaction medium was low when compared to the fermentative process for lactic acid production. An option to increase the concentration of lactic acid in the reaction medium and the productivity of the process would be to increase the amount of glycerol fed to the reactor. Table 3 presents the results obtained for the hydrothermal process operating at high glycerol concentration.

Increasing the amount of glycerol in the reaction mixture decreased significantly the yield of glycerol conversion into lactic acid, but increased the productivity. The yields observed in the process were low and the best condition gave a yield of $19.9 \%$. The process was mainly influenced by the $\mathrm{NaOH}$ to glycerol molar ratios, with low $\mathrm{NaOH}$ to glycerol molar ratios resulting in higher yields of lactic acid. At high glycerol concentration, the influence of temperature was lower. Statistical analysis also corroborates these observations (Table 2).

Table 3: Yield and lactic acid productivity for the hydrothermal treatment of glycerol carried out at high glycerol concentration.

\begin{tabular}{|c|c|c|c|c|c|c|}
\hline Run & $\begin{array}{c}\text { Temperature } \\
\left({ }^{\circ} \mathrm{C}\right)\end{array}$ & \begin{tabular}{|c}
$\begin{array}{c}\text { Water to Glycerol } \\
\text { volumetric ratio } \\
(\mathrm{v} / \mathrm{v})\end{array}$ \\
\end{tabular} & \begin{tabular}{|c}
$\begin{array}{c}\text { NaOH to Glycerol } \\
\text { molar ratio } \\
(\mathrm{mol} / \mathrm{mol})\end{array}$ \\
\end{tabular} & $\begin{array}{c}\text { Yield } \\
(\%)\end{array}$ & $\begin{array}{c}\text { Lactic Acid } \\
\text { Concentration } \\
(\mathrm{g} / \mathrm{L}) \\
\end{array}$ & $\begin{array}{c}\text { Lactic Acid } \\
\text { Productivity } \\
\text { (g/L.h) }\end{array}$ \\
\hline 10 & 260 & 1.0 & 0.04 & 19.9 & 122.5 & 40.8 \\
\hline 11 & 260 & 1.0 & 0.07 & 6.9 & 42.2 & 14.1 \\
\hline 12 & 260 & 1.0 & 0.11 & 2.3 & 13.9 & 4.6 \\
\hline 13 & 270 & 1.0 & 0.07 & 1.8 & 11.2 & 3.7 \\
\hline 14 & 270 & 1.0 & 0.11 & 10.3 & 63.4 & 21.1 \\
\hline 15 & 280 & 1.0 & 0.04 & 17.7 & 109.2 & 36.4 \\
\hline 16 & 280 & 1.0 & 0.07 & 17.2 & 105.9 & 35.3 \\
\hline 17 & 280 & 1.0 & 0.11 & 2.1 & 13.0 & 4.3 \\
\hline 18 & 270 & 0.8 & 0.07 & 6.2 & 42.5 & 14.2 \\
\hline 19 & 270 & 1.3 & 0.09 & 6.0 & 32.9 & 11.0 \\
\hline 20 & 270 & 1.7 & 0.12 & 5.0 & 22.9 & 7.6 \\
\hline
\end{tabular}


The most significant variable for the process was the concentration of hydroxide, having a negative effect on the yield of lactic acid (lower concentrations of $\mathrm{NaOH}$ resulted in higher yields). Temperature and water to glycerol volumetric ratio were not statistically significant for the process at high glycerol concentrations and water to glycerol volumetric ratios ranging from 0.8 to 1.3 . Temperatures ranging from 260 to $280{ }^{\circ} \mathrm{C}$ are required for the reaction, but the lower levels of temperature should be considered to run the hydrothermal process, since an increase in temperature did not change significantly the yield.

Although a decrease in yield was observed, a significant improvement in lactic acid productivity and concentration in the reaction media was obtained. The productivity of the process increased by $300 \%$ for the production of lactic acid, which is a considerable amount. The productivity of the hydrothermal process, under these conditions, was comparable to the productivity and lactic acid concentrations obtained by the best fermentative processes.

The yields and productivity of the process carried out with analytical grade and with crude glycerol were similar, with analytical grade glycerol resulting in a yield $2 \%$ higher than when operating with crude glycerol. From an economical point-of-view, it is not required to refine the crude glycerol before using it in the alkaline hydrothermal process. Only filtering would be required to remove suspended materials.

Table 4 presents the experiments carried out using $\mathrm{KOH}$ as catalyst. The yield and productivity obtained were, in most cases, lower than when using $\mathrm{NaOH}$ as catalyst. Shen et al. (2009) reported that the performance of the process when using $\mathrm{KOH}$ was superior to $\mathrm{NaOH}$ as a catalyst. However, the results obtained herein showed a different trend. The results show that $\mathrm{KOH}$ might be preferred when working at higher temperatures and higher water to glycerol volumetric ratio, while $\mathrm{NaOH}$ might be preferred when working at lower temperatures and lower water to glycerol volumetric ratio.

Longer reaction times did not contribute to a higher conversion. The reaction reached an equilibrium after 3 hours and no improvement in yield was observed. Thus, there is no need to spend more time and energy after 3 hours of reaction, since no increase in the conversion of glycerol into lactic acid will be attained.

The production of lactic acid through the hydrothermal process results in the formation of a racemic mixture of L-lactic acid and D-lactic acid. The racemic mixture can be used to produce several chemicals, such as ethyl lactate, propylene glycol, propylene oxide, acrylic acid and other green-labelled chemicals. The use of the racemic mixture in the production of poly(lactic acid) provides a polymer with a low degree of crystallinity and low tensile strength. The pure L-isomer is preferred to produce poly(lactic acid) because it provides a polymer with higher tensile strength and crystallinity and, in this case, the product derived from the fermentative process is preferred (Van Wouve et al., 2013). The racemic mixture, however, has been added to the pure Lisomer during polymerization to change the properties of poly(lactic acid), producing a wide range of physical properties (Datta and Henry, 2006).

One of the advantages of the fermentative process for the production of lactic acid is the possibility to start with several sources, such as sucrose, glucose, mannitol, fruit residues, glycerol and other sources (Gao et al., 2006; Göksungur et al., 2005; Marques et al., 2008; Silveira et al., 2010; Zhang and Vadlani, 2013). The hydrothermal process, in this sense, is limited to the use of glycerol, and its production should be linked to processes that generate large quantities of glycerol.

Table 4: Yield and lactic acid productivity for the hydrothermal treatment of glycerol carried out at high initial glycerol concentration using potassium hydroxide as catalyst.

\begin{tabular}{|c|c|c|c|c|c|c|}
\hline Run & $\begin{array}{c}\text { Temperature } \\
\left({ }^{\circ} \mathrm{C}\right)\end{array}$ & \begin{tabular}{|c|}
$\begin{array}{c}\text { Water to Glycerol } \\
\text { volumetric ratio } \\
(\mathrm{v} / \mathrm{v})\end{array}$ \\
\end{tabular} & $\begin{array}{c}\text { KOH to Glycerol } \\
\text { molar ratio } \\
(\mathrm{mol} / \mathrm{mol})\end{array}$ & $\begin{array}{c}\text { Yield } \\
(\%)\end{array}$ & $\begin{array}{c}\text { Lactic Acid } \\
\text { Concentration } \\
(\mathrm{g} / \mathrm{L}) \\
\end{array}$ & $\begin{array}{c}\text { Lactic Acid } \\
\text { Productivity } \\
\text { (g/L.h) }\end{array}$ \\
\hline 21 & 250 & 1.3 & 0.07 & 0.4 & 2.4 & 0.8 \\
\hline 22 & 260 & 0.8 & 0.04 & 2.6 & 18.1 & 6.0 \\
\hline 23 & 260 & 1.3 & 0.07 & 5.9 & 32.6 & 10.9 \\
\hline 24 & 260 & 1.0 & 0.06 & 1.4 & 8.4 & 2.8 \\
\hline 25 & 245 & 0.8 & 0.01 & 1.0 & 6.6 & 2.2 \\
\hline 26 & 250 & 0.8 & 0.01 & 6.2 & 42.2 & 14.1 \\
\hline 27 & 250 & 1.3 & 0.04 & 3.2 & 17.5 & 5.8 \\
\hline 28 & 255 & 0.8 & 0.03 & 2.6 & 18.1 & 6.0 \\
\hline 29 & 255 & 0.8 & 0.04 & 2.6 & 18.1 & 6.0 \\
\hline 30 & 250 & 1.3 & 0.05 & 25.1 & 137.3 & 45.8 \\
\hline
\end{tabular}


Nowadays, biodiesel plants are the main sources of glycerol and produce large quantities of this chemical. The availability of glycerol at low prices can boost the production of lactic acid by the hydrothermal process.

The atom efficiency of the hydrothermal process is very high $(97.8 \%)$, which is a positive feature of this process. The fermentative process has a lower atom efficiency $(78.9 \%)$ since fermentation of sucrose yields lactic acid, but also acetic acid and carbon dioxide.

Thermodynamic data show that the hydrothermal reaction pathway requires $5.6 \mathrm{~kJ} / \mathrm{mol}$ of lactic acid to run, while the fermentation of sucrose releases 227.5 $\mathrm{kJ} / \mathrm{mol}$ of lactic acid produced. From a thermodynamic point of view, considering only the enthalpy of formation, the fermentative process would be more efficient than the hydrothermal process. This efficiency may be lower because these values do not consider the energy required for heating, agitation and other energy requirements.

Reaction conditions are milder for the fermentative process, with temperatures ranging from ambient to $40{ }^{\circ} \mathrm{C}$ and atmospheric pressure. The processing time, however, is very long, with processing times over $8 \mathrm{~h}$ (Göksungur et al., 2005; Hugenholtz and Kleerebezem, 1999; Schepers et al., 2006; Zhang and Vadlani, 2013). The hydrothermal process requires higher temperatures and pressure, but has a very short reaction time. This time difference leads to a higher productivity of the hydrothermal process. The fermentative process requires the separation of the lactic acid from a more complex mixture that contains microorganisms, fermentation broth, residual sugars, lactic acid and other organic acids in lower concentration (Guilherme et al., 2011; Silveira et al., 2010). This complexity may lead to higher costs in the separation process, while the hydrothermal process requires a less complex separation system.

\section{CONCLUSIONS}

The results showed that the use of high concentrations of glycerol in the hydrothermal process increased the productivity and concentration of lactic acid in the reaction medium. The higher productivity however, was obtained at the expense of a lower yield of conversion of glycerol into lactic acid. At the optimal operating conditions, the hydrothermal process was able to produce lactic acid with higher productivities and concentrations of lactic acid than the fermentative process (currently the main industrial route for lactic acid production).

\section{ACKNOWLEDGEMENTS}

The authors acknowledge FUNCAP and Olvec Oleos Vegetais Ltda. for the financial support of this work.

\section{REFERENCES}

Budhavaram, N. K. and Fan, Z., Production of lactic acid from paper sludge using acid-tolerant, thermophilic Bacillus coagulans strains. Bioresource Technology, 100, 5966-5972 (2009).

Chen, L., Ren, S. and Ye, X. P., Lactic acid production from glycerol using $\mathrm{CaO}$ as solid base catalyst. Fuel Processing Technology, 120, 40-47 (2014).

Coelho, L. F., Lima, C. J. B., Rodovalho, C. M., Bernardo, M. P. and Contiero, J., Lactic acid production by new Lactobacillus plantarum LMISM6 grown in molasses: Optimization of medium composition. Brazilian Journal of Chemical Engineering, 28, 27-36 (2011).

Dasari, M. A., Kiatsimkul, P. P., Sutterlin, W. R. and Suppes, G. J., Low-pressure hydrogenolysis of glycerol to propylene glycol. Applied Catalysis, A, General, 281, 225 (2005).

Datta, R. and Henry, M., Lactic acid: Recent advances in products, processes and technologies a review. Journal of Chemical Technology and Biotechnology, 81, 1119-1129 (2006).

Gao, M. T., Hirata, M., Toorisaka, E. and Hano, T., Acid-hydrolysis of fish wastes for lactic acid fermentation. Bioresource Technology, 97, 2414-2420 (2006).

Göksungur, Y., Gündüz, M. and Harsa, S., Optimization of lactic acid production from whey by $\mathrm{L}$ casei NRRL B-441 immobilized in chitosan stabilized Ca-alginate beads. Journal of Chemical Technology \& Biotechnology, 80, 1282-1290 (2005).

Guilherme, A. A., Silveira, M. S., Fontes, C. P. M. L., Rodrigues, S. and Fernandes, F. A. N., Modeling and optimization of lactic acid production using cashew apple juice as substrate. Food and Bioprocess Technology, 5, 3151-3158 (2011).

Gullon, B., Yanez, R., Alonso, J. L. and Parajo, J. C., L-Lactic acid production from apple pomace by sequential hydrolysis and fermentation. Bioresource Technology, 99, 308-319 (2008).

He, W., Li, G., Kong, L., Wang, H., Huang, J. and Xu, J., Application of hydrothermal reaction in resource recovery of organic wastes. Resources Conservation and Recycling, 52, 691-699 (2008).

Hu, J., Liu, X., Wang, B., Pei, Y., Qiao, M. and Fan, $\mathrm{K}$., Reforming and hydrogenolysis of glycerol 
over $\mathrm{Ni} / \mathrm{ZnO}$ catalysts prepared by different methods. Chinese Journal of Catalysis, 33, 1266-1275 (2012).

Hugenholtz, J. and Kleerebezem, M., Metabolic engineering of lactic acid bacteria: Overview of the approaches and results of pathway rerouting involved in food fermentations. Current Opinions in Biotechnology, 10, 492-497 (1999).

Kishida, H., Jin, F., Zhou, Z., Moriya, T. and Enomoto, $\mathrm{H}$., Conversion of glycerine into lactic acid by alkaline hydrothermal reaction. Chemical Letters, 34, 1560-1561 (2005).

Marques, S., Santos, J. A. L., Girio, F. M. and Roseiro, J. C., Lactic acid production from recycled paper sludge by simultaneous saccharification and fermentation. Biochemical Engineering Journal, 41, 210-216 (2008).

Nancib, A., Nancib, N. and Boudrant, J., Production of lactic acid from date juice extract with free cells of single and mixed cultures of Lactobacillus casei and Lactococcus lactis. World Journal of Microbiology and Biotechnology, 25, 1423-1429 (2009).

Oliveira, R. F., Sousa, M., Lima, M. V. S., Barata, M. and Lima, H. O. S., Produção fermentativa de ácido lático a partir do melaço da cana-de-açúcar por Lactobacillus casei. Brazilian Journal of Food Technology, 7, 1-7 (2009). (In Portuguese).

Plessas, S., Bosnea, L., Psarianos, C., Koutinas, A. A., Marchant, R. and Banat, I. M., Lactic acid production by mixed cultures of Kluyveromyces marxianus, Lactobacillus delbrueckii ssp. bulgaricus and Lactobacillus helveticus. Bioresource Technology, 99, 5951-5955 (2008).

Purushothaman, R. K. P., van Haveren, J., van Es, D. S., Melián-Cabrera, I., Meeldijk, J. D. and Heeres, H. J., An efficient on pot conversion of glycerol to lactic acid using bimetallic gold-platinum catalysts on a nanocrystalline $\mathrm{CeO}_{2}$ support. Applied Catalysis B. Environmental, 147, 92-100 (2014).

Ramírez-López, C. A., Ochoa-Gómez, J. R., Gil-Río, S., Gómez-Jiménez-Aberasturi, O. and TorrecillaSoria, J., Chemicals from biomass: Synthesis of lactic acid by alkaline hydrothermal conversion of sorbitol. Journal of Chemical Technology \& Biotechnology, 86, 867-874 (2011).
Ramírez-López, C. A., Ochoa-Gomez, J. R., FernándezSantos, M., Gomez-Jimenez-Aberasturi, O., AlonsoVicario, A. and Torrecilla-Soria, J., Synthesis of lactic acid by alkaline hydrothermal conversion of glycerol at high glycerol concentration. Industrial \& Engineering Chemistry Research, 49, 6270-6278 (2010).

Roy, D., Subramaniam, B. and Chaudhari, R. V., Cubased catalysts show low temperature activity for glycerol conversion to lactic acid. ACS Catalysis, 1, 548-551 (2011).

Savage, P. E., Organic chemical reactions in supercritical water. Chemical Research, 99, 603-621 (1999).

Schepers, A. W., Thibault, J. and Lacroix, C., Continuous lactic acid production in whey permeate/ yeast extract medium with immobilized Lactobacillus helveticus in a two-stage process: Model and experiments. Enzyme Microb. Technology, 38, 324-337 (2006).

Shen, Z., Jin, F., Zhang, Y., Wu, B., Kishita, A., Tohji, K. and Kishida, H., Effect of alkaline catalysts on hydrothermal conversion of glycerin into lactic acid. Industrial \& Engineering Chemistry Research, 48, 8920-8925 (2009).

Silveira, M. S., Fontes, C. P. M. L., Guilherme, A. A., Fernandes, F. A. N. and Rodrigues, S., Cashew apple juice as substrate for lactic acid production. Food and Bioprocess Technology, 5, 947953 (2010).

Van Wouve, P., Dusselier, M., Basic, A. and Sels, B. F., Bridging racemic lactate esters with stereoselective polylactic acid using commercial lipase catalysis. Green Chemistry, 15, 2817-2824 (2013).

Xu, J., Zhang, H., Zhao, Y., Yu, B., Chen, S., Li, Y., Liu, Z., Selective oxidation of glycerol to lactic acid under acidic conditions using $\mathrm{AuPd} / \mathrm{TiO}_{2}$ catalyst. Green Chemistry, 15, 1520-1525 (2013).

Zhang, Y. and Vadlani, P. V., D-lactic acid biosynthesis from biomass-derived sugars via lactobacillus delbrueckii fermentation. Bioprocess and Biosystem Engineering, 36, 1897-1904 (2013).

Zhou, H., Jin, F., Wu, B., Cao, J., Duan, X. and Kishita, A., Production of lactic acid from C-6 polyols by alkaline hydrothermal reactions. Journal of Physics, Conference Series, 215, 012125 (2010). 